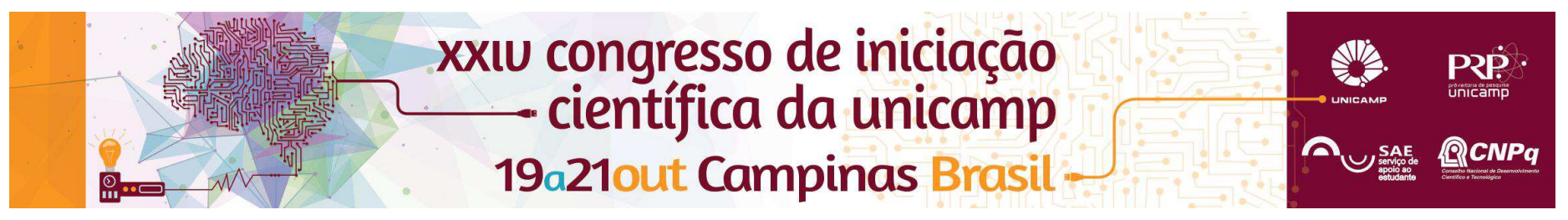

\title{
Display Aéreo Rotativo
}

\section{Beatriz S. Oliveira*, Larissa R. Silvestre, Nicolas C. Vieira, João V.V. D’Abreu}

\section{Resumo}

O dispositivo explora a ilusão de ótica, pois nosso sistema visual é muito limitado para processar com precisão todas as informações que nossos olhos absorvem, portanto, ele funciona com base na interpretação mais provável.

Palavras-chave: llusão de ótica, programação, leds.

\section{Introdução}

Para o desenvolvimento do Display Aéreo, acoplamos LED's vermelhos em uma placa que funciona como uma hélice, que ao executar sua programação, será possível ver os LED's piscando em uma seqüência. Desejávamos unir a mecânica e a robótica de forma à criar um projeto divertido aos olhos, brincando com a visão do expectador, em um desafio de tentar entender conceitos como movimento angular e ilusão de ótica de uma forma mais didática e ao mesmo tempo um exemplo que saísse totalmente do abstrato.

Após aprender sobre programação e seus princípios básicos, elaboramos um projeto um pouco mais avançado do que apenas trabalhar com LEGO. Utilizamos uma placa arduino onde foram feitas as programações, dez LED's vermelhos alinhados sobre ela, uma bateria de Lítio para a alimentação da placa e um motor [...] que fazia a hélice girar.

\section{Resultados e Discussão}

Nossa idéia era poder escrever a palavra PIBIC nos LED's, de forma que quando a hélice se movimentasse fosse possível formar cada uma das letras e com nossa ilusão de ótica ler a palavra. Começamos devagar tentando formar a letra " 1 " porém, encontramos algumas dificuldades, nosso motor não tinha força o suficiente e também não conseguíamos saber quando a hélice completava a volta, isso nos prejudicou em nossas tentativas. Então decidimos fazer os LED's piscarem, que através da programação formaremos figuras.

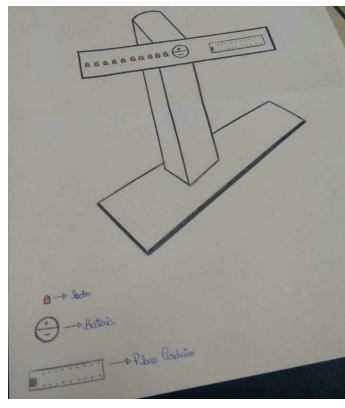

Figura 1: protótipo feito a mão

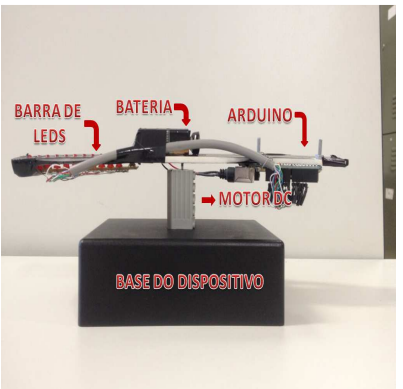

Figura 2: legendas indicando os materiais do projeto finalizado

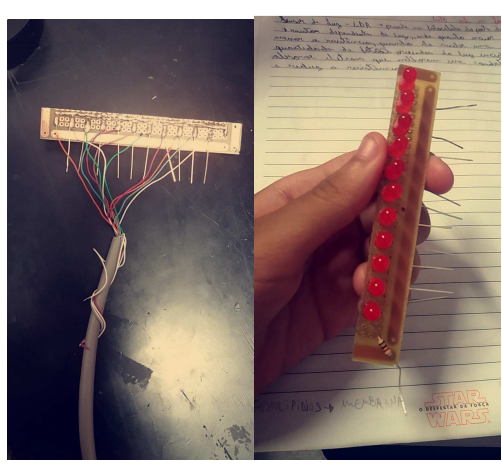

Figura 3: Placa de leds

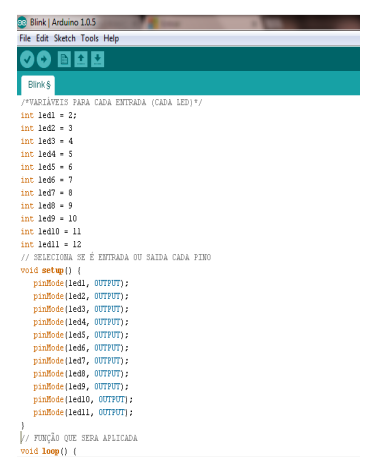

Figura 4 : programação

\section{Conclusões}

Pode-se concluir nesse projeto que existe a ilusão de ótica, pois ao rotacionar a placa com os LED'S ela forma uma figura, o que podemos obter através da programação. Aprendemos a programar o básico, a construir o projeto trabalhando com vários materiais e ferramentas,e passamos pela experiência da ilusão de ótica.

\section{Agradecimentos}

Agradecemos aos monitores, ao professor João D'Abreu, e ao projeto PIBIC- EM.

\footnotetext{
1 http://www.shutterstock.com/pt/blog/ilusoes-de-otica-por-que-nossos-olhosenganam-nossas-mentes
}

2 http://professormarlonnardi.blogspot 